\title{
Effect of Insect Exclusion on the Incidence of Yellow Vine Disease and of the Associated Bacterium in Squash
}

\author{
Blake Bextine, Astri Wayadande, Department of Entomology and Plant Pathology, Oklahoma State University, \\ Stillwater 74078; B. D. Bruton, S. D. Pair, U.S. Department of Agriculture, Agricultural Research Service, Lane, \\ OK 74555; Forrest Mitchell, Texas Agricultural Experiment Station, Stephenville 76401; and Jacqueline Fletcher, \\ Department of Entomology and Plant Pathology, Oklahoma State University, Stillwater 74078
}

\begin{abstract}
Bextine, B., Wayadande, A., Bruton, B. D., Pair, S. D., Mitchell, F., and Fletcher, J. 2001. Effect of insect exclusion on the incidence of yellow vine disease and of the associated bacterium in squash. Plant Dis. 85:875-878.

Yellow vine (YV) of cucurbits, associated with a phloem-limited bacterium, causes rapid wilting and death in affected plants. In a previous study, experimental insecticide-treated plots had a lower incidence of YV than untreated plots, suggesting that insects were involved in the transmission of the bacterium. In the study reported here, we compared the incidence of YV and polymerase chain reaction (PCR) detection of the YV bacterium in noncovered squash plants (Cucurbita pepo var. melopepo) with plants covered with fine-mesh fabric secured in such a way that insects were excluded. Rows of squash were covered with row mesh cover that was stretched over hoops and anchored in the soil. The row cover was removed after 40 or 50 days, at which time all plants were sampled destructively by harvesting the crown and root. In the first experiment, $3 \%$ of the noncovered plants had foliar symptoms, $7 \%$ were positive with the use of Dienes' stain, and $25 \%$ were positive when analyzed by PCR with specific primers. No covered plants were positive by any detection method, and no plants in the second experiment had foliar symptoms or tested positive with Dienes' stain. However, $20 \%$ of noncovered and $0 \%$ of covered plants were PCR positive. These data support the hypothesis that insects were involved in the transmission of the bacterium.
\end{abstract}

Cucurbit production in Texas and Oklahoma accounts for over $\$ 100$ million in annual grower income (3). In 1988, a newly discovered vine decline disease in squash and pumpkin was observed in Oklahoma and north central Texas (4). Similar disease symptoms and serious crop losses were observed in watermelon in Oklahoma and north Texas in 1991. The disease, called yellow vine (3), is distinctly different from other vine declines of squash (Cucurbita pepo var. melopepo) and pumpkin (C. pepo var. pepo) (13). Two distinct symptoms are exhibited by diseased plants (3). In early season following fruit set and the beginning of fruit enlargement, there is often sudden wilting and death of plants in a single day, without leaf yellowing. The more prominent symptoms of leaf yellowing and gradual decline generally occur approximately 7 to 14 days prior to harvest. A honey-brown discoloration of the phloem is prominent in the cross section of the primary root and crown, a symptom that was often but not

Corresponding author: J. Fletcher

E-mail: jaf2394@okstate.edu

Accepted for publication 16 April 2001.

Publication no. D-2001-0524-01R

(C) 2001 The American Phytopathological Society always observed throughout the terminal portion of the vine section as well. Root rot is not a symptom of yellow vine, but secondary root invaders may cause tissue breakdown as plants decline (3). Yellow vine has not been observed in cucumbers but has occurred frequently in summer and winter squash, pumpkin, watermelon, and cantaloupe (11).

Since the first observations of yellow vine in cucurbits in 1988 (4), numerous biotic and abiotic causes have been theorized, as noted in previous reports $(3,5)$. Among these are herbicide damage, nutrient imbalance, Fusarium wilt, charcoal rot, Monosporascus vine decline, and Lettuce infectious yellows virus. None of these, however, were associated consistently with the incidence of yellow vine (3). Dienes' stain, previously reported to be specific for mollicutes (6), consistently stained the phloem of symptomatic plants, although no other evidence of spiroplasma or phytoplasma involvement was found (3). When electron microscopy was used, yellow vine symptoms were associated consistently with the presence of a phloem-inhabiting bacterium, and polymerase chain reaction (PCR) primers were designed to detect this organism $(2,8)$. When these primers were used, the bacterium was detected consistently in symptomatic plants, although not in asymptomatic plants. The use of PCR facilitated the detection of the yellow vine bacterium in cucurbit crops (3) and insects (unpublished data).

In related studies, soil fumigation did not affect the incidence of yellow vine disease and foliar insecticide treatments lowered disease incidence (4), leading to the hypothesis that the yellow vine bacterium is transmitted by an insect vector. Preliminary transmission tests performed with a number of different cucurbit insect pests, however, failed to move the bacterium from infected to healthy plants $(3,10)$.

Row covers are used in horticultural crops as barriers against insects and associated diseases. Research in melon crops demonstrated that disease transmission by insects is reduced by the use of floating row covers made from Reemay (Old Hickory, TN), a spun, bonded polyester material, thin enough to allow sunlight and air flow but fine enough to exclude insects $(9,12)$. In this study, to further evaluate the hypothesis of insect transmission of the yellow vine bacterium, an insect exclusion experiment was used to test whether physical exclusion of aboveground insects from cucurbit plants affect the incidence of disease and/or the presence of the yellow vine bacterium in yellow squash.

\section{MATERIALS AND METHODS}

Experiment one. Insect exclusion tests were performed at the Oklahoma State University Plant Pathology Farm in Stillwater. A randomized, complete block design, with four replications of two treatments (covered rows and noncovered rows), was used. Yellow squash (C. pepo var. melopepo cv. Lemon Drop) was chosen as a test species because of its known susceptibility and because vines of this species are more restricted in growth habit than those of watermelon and pumpkin, facilitating complete physical exclusion of aboveground insects. Prior to the first experiment, plots were disked and the preplant herbicides Alanap and Prefar were applied by a $\mathrm{CO}_{2}$ wheelbarrow plot sprayer (2.18 liters/hectare). Seeds were planted on 24 May, 1999, at a depth of approximately $3 \mathrm{~cm}$, with two seeds per hill at $0.45-\mathrm{m}$ intervals in eight $25-\mathrm{m}$ rows. On the same date, two rows of 2-week-old, greenhousegrown seedlings of the same cultivar were transplanted, one per hill, at $0.45-\mathrm{m}$ intervals around the perimeter of the test plot. These borders were planted to reduce the 
possibility of an edge effect, i.e., a higher incidence of disease in the outer rows as a result of greater accessibility by insects. Within $24 \mathrm{~h}$ of seed sowing, four of the eight rows were covered with Reemay $\left(1.70 \times 27 \mathrm{~m}, 15.6 \mathrm{~g} / \mathrm{m}^{2}\right)$, stretched over flexible PVC arches placed at 4-m intervals and sealed and anchored by covering the fabric edges with soil. The Reemay was checked twice a week to ensure that insects could not gain access. Two $7.62 \times$ $12.70 \mathrm{~cm}$ Sensor yellow sticky traps (Whitmire Micro-Gen, St. Louis, MO) were placed in each row, covered and nonncovered. These traps were suspended $3 \mathrm{~m}$ apart and $20 \mathrm{~cm}$ above the soil surface by a $30-\mathrm{cm}$ piece of 14 -gauge galvanized steel wire (Anchor Wire, Goodlettsville, $\mathrm{TN}$ ), which was anchored in the soil under the row cover. The traps were checked each week, without disturbing the Reemay over the covered rows, to monitor insect presence. Soaker hose (Colorite Plastic, Ridgefield, NJ) was deployed along the length of each treatment and the control row prior to seeding and row covering, and plants were watered as needed. Border plants were watered directly by hose.

Sample collection. Row covers were removed when the first symptoms of yellow vine occurred (50 days postplant) and foliar symptoms were noted. The crown and root of every plant, in experiment and border rows, were collected and stored in plastic bags at $4^{\circ} \mathrm{C}$, for up to 5 days. Samples were screened for the presence of the yellow vine bacterium by Dienes' stain of hand-cut crown sections, following the protocol of Deeley $(3,6)$, and by PCR with a primer set (YV 1-2) specific to the yellow vine bacterium $(2,8)$.

Experiment two. In the second experiment, squash seeds were planted on 15 July, 1999. As in the first experiment, a randomized, complete block design with four replications of two treatments (covered rows and noncovered rows) was used.
Slight modifications from the design of the first experiment were made. To maximize the likelihood of infection, rows were arranged as the edges of a rectangle, with nothing planted in the center, so that all plants were at the borders of the field. Samples in the second experiment were collected after 40 days rather than 50 days, even though symptoms had not appeared in any of the plants, because high summer temperatures and the lack of precipitation were beginning to negatively impact all plants. The samples were stored and tested in the same manner as in the first experiment.

DNA extraction and PCR. DNA was extracted from the plant samples with a GeneClean II extraction kit (Bio 101, Vista, CA) but with the use of a protocol modified from that of the manufacturer. Approximately $0.2 \mathrm{~g}$ of crown tissue was ground with a plastic pestle in $160 \mu \mathrm{l}$ of Lytic buffer in a $1.5-\mathrm{ml}$ microfuge tube. Forty microliters of 5\% sodium Sarkosyl was added, and the tube was incubated at $55^{\circ} \mathrm{C}$ for $6 \mathrm{~min}$ and centrifuged $(13,200 \times g$ for $6 \mathrm{~min}$ ) to pellet cellular debris. Meanwhile, $400 \mu \mathrm{l}$ of GC Spin Glassmilk (Bio 101) was added to a spin column, which is a specialized microfuge catch tube with a removable filter $(0.45 \mu \mathrm{m})$. Supernatant was transferred to the spin column, incubated for $5 \mathrm{~min}$ (inverted once per minute), and centrifuged $(10,000 \times g$ for $30 \mathrm{~s}$, room temperature). The filter containing the silica beads and sample DNA was replaced in the catch tube and washed twice with $400 \mu \mathrm{l}$ of GC Spin New Wash (Bio 101). After the second wash, the tube was centrifuged for $1 \mathrm{~min}(13,200 \times g)$ to remove any remaining ethanol. In a fresh catch tube, $100 \mu \mathrm{l}$ of GC spin elution solution (Bio 101) was added to the filter and agitated to resuspend the beads before centrifuging $13,200 \times g$ for $1 \mathrm{~min}$. The eluent containing extracted DNA was saved and kept refrigerated until PCR was run.

Table 1. Influence of row covering on incidence of yellow vine and detection of the associated bacterium in yellow squash (Cucurbita pepo var. melopepo cv. Lemon Drop) for the first exclusion experiment $^{\mathrm{a}}$

\begin{tabular}{lccccc}
\hline $\begin{array}{l}\text { Treatment } \\
\text { (row) }\end{array}$ & $\begin{array}{c}\text { Plants } \\
\text { (no.) }\end{array}$ & $\begin{array}{c}\text { Symptomatic } \\
\text { plants (no.) }\end{array}$ & $\begin{array}{c}\text { Dienes' stain } \\
\text { positive (no.) }\end{array}$ & $\begin{array}{c}\text { PCR } \\
\text { positive (no.) })^{\mathbf{b}, \mathbf{c}}\end{array}$ & $\begin{array}{c}\text { Incidence } \\
\text { by PCR (\%) }\end{array}$ \\
\hline Covered & & & & & \\
$\quad 1$ & 26 & 0 & 0 & 0 & 0.0 \\
2 & 11 & 0 & 0 & 0 & 0.0 \\
3 & 19 & 0 & 0 & 0 & 0.0 \\
4 & 15 & 0 & 0 & 0 & 0.0 \\
Total & 70 & 0 & 0 & 0 & \\
Noncovered & & & & & 0.0 \\
1 & 15 & 2 & 3 & 7 & 21.1 \\
2 & 19 & 0 & 1 & 4 & 0.0 \\
3 & 15 & 0 & 0 & 0 & 40.1 \\
4 & 10 & 0 & 0 & 4 & 25.4 \\
Total & 59 & 2 & 4 & 15 & \\
\hline
\end{tabular}

a Planted 24 May 1999.

${ }^{\mathrm{b}} \mathrm{PCR}=$ polymerase chain reaction

${ }^{\mathrm{c}}$ Categorical variables are different by Fisher's exact test $(P=0.071)$.

${ }^{\mathrm{d}}$ Means are significantly different by exact binomial test $(P<0.001)$.

PCR reactions were carried out in $25-\mu l$ reaction mixtures containing 10 to $50 \mathrm{ng}$ of genomic DNA template, $0.2 \mathrm{mM}$ (each) deoxynucleoside triphosphate, $0.625 \mathrm{U}$ of Taq DNA polymerase (Promega, Madison, WI), $0.2 \mu \mathrm{M}$ forward primer YV1 (5'GGGAGCTTGCTCCCCGG-3') (2), and reverse primer YV4 (5'-AACGTCAATTGATGAACGTATTAAGT-3') (8) in a PCR buffer (10 mM Tris-HCl, pH 8.3; 5 nM EDTA; $25 \mathrm{mM} \mathrm{KCl} ; 4 \mathrm{mM} \mathrm{MgCl}_{2}$ ). A PTC-100 thermocycler (MJ Research, Watertown, MA) was programmed for 3 min at $95^{\circ} \mathrm{C}$, followed by 34 cycles of $30 \mathrm{~s}$ at $95^{\circ} \mathrm{C}, 30 \mathrm{~s}$ at $55^{\circ} \mathrm{C}$, and $2 \mathrm{~min}$ at $72^{\circ} \mathrm{C}$, with a final extension at $72^{\circ} \mathrm{C}$ for $10 \mathrm{~min}$. A $10-\mu l$ aliquot of each PCR sample was separated on $1.2 \%$ horizontal agarose gel at $10 \mathrm{~V}$ per $\mathrm{cm}$ for $120 \mathrm{~min}$ in Tris-borateEDTA buffer (0.1 M Tris-HCl, pH 8.0; 0.1 $\mathrm{M}$ boric acid; $2 \mathrm{mM}$ EDTA). A 100-bp DNA ladder was used as a size marker. The gel was stained with $0.5 \mu \mathrm{g}$ of ethidium bromide per ml. A sample was considered positive for the presence of the yellow vine bacterium, if a 308-bp DNA band was visualized with UV light.

Analysis of field data. Data on the incidence of the yellow vine bacterium in both experiments were analyzed with two statistical tests. The exact binomial test (1) is based on the normal approximation of populations to the binomial distribution, i.e., if row cover has no effect on incidence of the bacterium, we expect the percent incidence between the two test plot populations (covered and noncovered) to be the same. The exact binomial test determines the probability that differences in means occur in varying degrees. Fisher's exact test determines whether there is any relationship between two categorical variables. The right-tailed version of the test is used when the alternative to independence is a positive association between the variables. In this case, the variables are covered/noncovered and incidence/no incidence.

\section{RESULTS}

Experiment one. Of the 70 plants grown under row cover, none appeared symptomatic or tested positive by Dienes' stain or yellow vine-specific PCR (Table $1)$. Of the 59 plants collected from the noncovered rows, two showed strong yellow vine foliar symptoms, including yellowing, wilting, and general and rapid decline of the vine. Four of the 59 plants (7\%), including the two with foliar symptoms, had phloem discoloration and tested positive by Dienes' stain, and 15 plants $(25.42 \%)$, including the seven that tested positive by Dienes' stain, were PCR positive for the presence of the yellow vine bacterium. PCR-positive samples occurred in three of the four noncovered test rows. Additionally, 11 of the 170 plants $(6.5 \%)$ in the border rows were symptomatic and 35 of the 170 plants $(20.6 \%)$ tested positive for the yellow vine bacterium by PCR. 
Although the yellow vine bacterium was not detected in any of the covered rows, plants in these treatments were smaller than their noncovered counterparts and slightly yellowed. The slight yellow appearance, however, was distinguishable from yellow vine symptoms. The fruit in these rows were smaller and misshapen, probably because wind pollination of $\mathrm{cu}-$ curbits is inefficient (13) and insect pollination was prevented by the row cover. Insects such as spotted cucumber beetles (Diabrotica undecimpunctata howardi), striped cucumber beetles (Acalymma vittatum), squash bugs (Anasa tristis), or leafhoppers, which commonly feed on cucurbits, were not on the yellow sticky traps under the row cover. In fact, only small flies (Diptera) were found. The fact that no potential insect vectors were on the yellow sticky traps confirmed the effectiveness of the row cover. In noncovered rows, in addition to the small flies, leafhoppers Exitianus exitiosis and Macrosteles $\mathrm{sp}$. were collected in moderate numbers at all collection times throughout the season. Several other cucurbit pests, including squash bugs, spotted cucumber beetles, striped cucumber beetles, and several other unidentified leafhopper species, were inconsistently present in low densities. During the 50 days after planting, weeds were not controlled in either treatment and became quite numerous.

The exact binomial test considered individual plants as the experimental units on the basis of the probability that $0 \%$ incidence would occur in the covered plants if the row cover had no effect on the outcome. This test was used to determine that the difference in incidence of the yellow vine bacterium between the covered $(25.42 \%)$ and noncovered (0\%) plant populations was highly significant $(P<0.001)$.

The right-tailed version of Fisher's exact test was used to determine whether there was a relationship between the two categorical variables, covered/noncovered and incidence/no incidence. In this test, each of the four rows rather than each individual plant was considered as an experimental unit because rows, not individual plants, were covered. This test was used to determine that the difference in incidence of yellow vine bacterium between treatments was significant at the $93 \%$ level $(P=$ 0.071 ), a confidence level considered acceptable because of the small sample size (four rows) and the nature of this statistical test.

Experiment two. Stand establishment was poor and plant growth less vigorous in the second experiment than in the first, possibly because the average temperature over the course of the experiment was relatively cool $\left(25.29^{\circ} \mathrm{C}\right)$ during the first experiment and much warmer $\left(30.48^{\circ} \mathrm{C}\right)$ in the second. In addition, total precipitation was $27.86 \mathrm{~cm}$ during the first experiment but only $3.15 \mathrm{~cm}$ during the second. Yellow sticky traps again indicated that the row cover was effective in excluding insects. Only small flies were on the traps in covered rows. Several cucurbit insect pests, including squash bugs, spotted cucumber beetles, striped cucumber beetles, and several unidentified leafhopper species, were observed inconsistently in noncovered rows in low densities. The leafhopper species E. exitiosis and Macrosteles sp. were collected in moderate numbers throughout the growing season.

No plants had yellow vine symptoms or tested positive with Dienes' stain in either covered or noncovered rows. When screened by PCR, none of the 22 covered plants $(0 \%)$ tested positive, whereas three of the 15 noncovered plants $(20 \%)$ tested positive (Table 2). The difference between the expected and observed proportion was significant (exact binomial test, $P<0.007$; Fisher's exact test, $P=0.214$ ).

\section{DISCUSSION}

During the course of this study, the yellow vine bacterium was not detected by PCR in yellow squash plants protected by row cover, whereas the bacterium was detected in 20 to $25 \%$ of noncovered plants. It must be noted that the row cover restricted access to plants by insects as well as birds, rodents, and other animals, thereby altering environmental conditions and causing higher soil and air temperatures and higher humidity (7). When the row cover experiment results are considered in conjunction with those of previous work showing disease suppression by insecticide application (4), a clear association between the restriction of insect access to plants and a lack of the putative pathogen emerges. Thus, the data presented here support the hypothesis that the yellow vine bacterium is insect transmitted. Furthermore, low incidence of the yellow vine bacterium in commercial fields is not unusual. Disease incidence can range from less than 5 to $100 \%$ (4). This fluctuation in percentage of incidence, along with a fluctuation in insect population and natural distribution, probably accounts for the lack of yellow vine in some noncovered rows. Randomized, complete block design was used to control for these natural inconsistencies.

Dienes' stain, initially applied in order to screen for mollicutes (spiroplasmas and phytoplasmas) in plant tissues (6), consistently gave positive results with yellow vine-affected plants exhibiting phloem discoloration (3). All plants that tested positive by Dienes' stain also tested positive by PCR. In addition, several Dienes' stain-negative plants tested positive by PCR. Among available assays, PCR is the most reliable and most sensitive test for the presence of yellow vine bacterium. The small percentage of PCR-positive but asymptomatic field plants may reflect early stages of infection by the yellow vine bacterium.

The experiments reported here were designed to determine whether the exclusion of aboveground insects could affect yellow vine disease incidence and/or the occurrence of the yellow vine bacterium in exposed plants. The absence of yellow vine disease in covered plots suggests that these exclusion methods might be adapted for use by growers. Several complications, however, would have to be overcome. Covered and noncovered plants flowered and bore fruit, although covered plants produced fewer fruits. Squash that were produced were small and misshapen because of the lack of adequate insect pollination (13). Row cover used to protect plants from insect feeding prior to flowering and then removed to allow insect pollination to occur may protect plants from yellow vine disease early in the season, yet allow for normal fruit production later. Insect pollinators also could be added under row cover during flowering, although

Table 2. Influence of row covering on incidence of yellow vine and detection of the associated bacterium in yellow squash (Cucurbita pepo var. melopepo cv. Lemon Drop) for the second exclusion experiment $^{\mathrm{a}}$

\begin{tabular}{lccccc}
\hline $\begin{array}{l}\text { Treatment } \\
\text { (row) }\end{array}$ & $\begin{array}{c}\text { Plants } \\
\text { (no.) }\end{array}$ & $\begin{array}{c}\text { Symptomatic } \\
\text { plants (no.) }\end{array}$ & $\begin{array}{c}\text { Dienes' stain } \\
\text { positive (no.) }\end{array}$ & $\begin{array}{c}\text { PCR } \\
\text { positive (no.) }^{\mathbf{b}, \mathbf{c}}\end{array}$ & $\begin{array}{c}\text { Incidence } \\
\text { by PCR (\%) }\end{array}$ \\
\hline Covered & & & & & 0.0 \\
1 & 7 & 0 & 0 & 0 & 0.0 \\
2 & 10 & 0 & 0 & 0 & 0.0 \\
3 & 3 & 0 & 0 & 0 & 0.0 \\
4 & 2 & 0 & 0 & 0 & 0.0 \\
Total & 22 & 0 & 0 & 0 & 25.0 \\
Noncovered & & & & & 0.0 \\
1 & 8 & 0 & 0 & 2 & 3.3 \\
2 & 3 & 0 & 0 & 0 & 0.0 \\
3 & 3 & 0 & 0 & 1 & 20.0 \\
4 & 1 & 0 & 0 & 0 & 3 \\
Total & 15 & 0 & 0 & & \\
\hline
\end{tabular}

\footnotetext{
a Planted 15 July 1999.

b $\mathrm{PCR}=$ polymerase chain reaction

c Categorical variables are different by Fisher's exact test $(P=0.214)$.

${ }^{\mathrm{d}}$ Means are significantly different by exact binomial test $(P<0.007)$.
} 
harvesting under the row cover would be difficult. Despite preplant herbicide applications, weeds are a considerable problem and difficult to control without disrupting row cover. Maintenance of the row cover during the experiment was time consuming because constant attention was necessary to quickly repair small tears in the fabric, tears which otherwise could have allowed for insect entrance.

The original intent of our studies was to determine whether excluding aboveground insects from yellow squash plants would reduce the incidence of disease and/or occurrence of the yellow vine bacterium. Our results showed a complete absence of the disease and the associated bacterium in covered rows, providing strong circumstantial evidence for insect involvement in the transmission of the bacterium associated with yellow vine disease of cucurbits.

\section{ACKNOWLEDGMENTS}

This research was supported by the Oklahoma Agricultural Experiment Station and the USDASRIPM program. We thank M. Berg, K. Giles, and J. Damicone for review of the manuscript.
LITERATURE CITED

1. Agresti, A. 1990. Categorical Data Analysis. Wiley, New York.

2. Avila, F. J., Bruton, B. D., Fletcher, J., Sherwood, J. L., Pair, S. D., and Melcher, U. 1998. Polymerase chain reaction detection and phylogenetic characterization of an agent associated with yellow vine disease of cucurbits. Phytopathology 88:428-436.

3. Bruton, B. D., Fletcher, J., Pair, S. D., Shaw, M., and Sittertz-Bhatkar, H. 1998. Association of a phloem-limited bacterium with yellow vine disease in cucurbits. Plant Dis. 82:512520.

4. Bruton, B. D., Pair, S. D., Popham, T. W., and Cartwright, B. 1995. Occurrence of primary insect pests in relation to yellow vine, a new disease of squash and pumpkin: Subtropical plant science. J. Rio Grande Val. Hortic. Soc. 47:53-58.

5. Bruton, B. D., Pair, S. D., and Wann, E. V. 1995. Yellow vine disease of watermelon and cantaloupe in Texas and Oklahoma. SCARL101. USDA-ARS, Lane, OK.

6. Deeley, J., Stevens, W. A., and Fox, R. T. V. 1979. Use of Dienes' stain to detect plant diseases induced by mycoplasmalike organisms. Phytopathology 69:1169-1171.

7. Mansour, N. S. 1984. Floating row covers give plants TLC. Am. Veg. Grower 32(12):810.
8. Melcher, U., Mitchell, F., Pair, S., Fletcher, J., and Bruton, B. 1999. New primer sets distinguish the cucurbit yellow vine bacterium from an insect endosymbiont. (Abstr.) Phytopathology 89:S95.

9. Natwick, E. T., and Laemmlen, F. F. 1993 Protection from phytophagous insects and virus vectors in honeydew melons using row covers. Fla. Entomol. 76:120-126.

10. Pair, S. D., Bruton, B. D., Cartwright, B., and Duthie, J. 1993 Status of search for insect vectors of yellow vine in cucurbits. Pages 149-151 in: 12th Annual Oklahoma Horticulture Industries Conference. B. D McGraw, ed. Oklahoma State University, Stillwater.

11. Pair, S. D., Fletcher, J., Bruton, B. D., and Mitchell, F. 1998. Advances in yellow vine disease research. Pages 287-290 in: 17th Annual Horticulture Industries Show. B. D. McGraw, ed. Tulsa Community College, Tulsa, OK.

12. Perring, T. M., Royalty, R. N., and Farrar, C. A. 1989. Floating row covers for the exclusion of virus vectors and the effect on disease incidence and yield of cantaloupe. J. Econ. Entomol. 82:1709-1715.

13. Zitter, T. A., Hopkins, D. L., and Thomas, C. E. 1998. Compendium of Cucurbit Diseases American Phytopathological Society, St. Paul, MN. 